\title{
Definição e estrutura dos direitos fundamentais*
}

\section{The definition and structure of fundamental rights}

\author{
Paulo Victor Vieira da Rocha*
}

\section{RESUMO}

O presente trabalho procura definir direitos fundamentais, assumindo como premissa sua gênese na doutrina dos direitos humanos e na posterior positivação desses, para depois demonstrar a atual distinção entre os conceitos não só no plano doutrinário, mas também dogmático. A partir da definição proposta de direitos fundamentais, que tem suporte no direito positivo brasileiro - mas que pode ser aplicada pelo menos à grande maioria dos estados democráticos de direito -, se chega a uma tenativa de compreender a estrutura lógica das normas que veiculam direitos fundamentais, inclusive, para tentar responder à questão sobre direitos relacionados à matéria tributária serem ou não fundamentais, no sentido analítico

* Artigo recebido em 24 de maio de 2012 e aprovado em 10 de agosto de 2012.

** Doutor (2014) e mestre (2010) em direito econômico, financeiro e tributário na Universidade de São Paulo (USP). Pesquisador visitante na Universidade de Heidelberg em programa de doutorado sanduíche (2013/2014). Juiz substituto do Tribunal de Impostos e Taxas do Estado de São Paulo (2014/2015). Pesquisador da Universidade de São Paulo, integrante do grupo internacional de pesquisa "Development, Sustainability and Transparency". Professor convidado (conferencista) do Instituto Brasileiro de Direito Tributário (IBDT/USP). Pós-graduado (especialista, 2006) em direito tributário pela Universidade Presbiteriana Mackenzie. Advogado em São Paulo e em Manaus. Universidade de São Paulo, São Paulo, São Paulo, Brasil. E-mail: paulovictor@usp.br. 
ou estrutural. Ao final, busca-se fazer uma defesa de certo modelo de aplicação dos direitos fundamentais com vistas à sua maior realização possível.

\section{PALAVRAS-CHAVE}

Direitos fundamentais - definição - estrutura lógica - direitos humanos

\section{ABSTRACT}

The present essay aims to define fundamental rights, taking for granted its genesis on the doctrine of human rights and on its subsequent constitutional prescription, to then demonstrate the current distinction between the concepts not only on the doctrinary, but also on the dogmatic plan. Since the proposed definition of fundamental rights, that is based on the Brazilian Law - but can be applied at least to the great majority of the Democratic States - the essay gets to an attempt to compreehend the logical structure of the norms that prescribe fundamental rights, also to answer the question wether rights concerning taxation are fundamental, on the analytical or structural sense. Finally, one tries to make a defense of a certain mode of application of fundamental rights searching its implementation as most as possible.

\section{KEYWORDS}

Fundamental rights - definition - logical structure - human rights

\section{Introdução}

Os debates sobre direitos fundamentais são cada vez mais intensos e numerosos nos Estados constitucionais do período pós-guerra. E um dos problemas que permeiam essas discussões é a falta de definição do que sejam exatamente direitos fundamentais, bem como o que os diferenciaria daqueles "não fundamentais". Por exemplo, aqueles que têm a tributação como seu principal objeto de pesquisa são, por vezes, questionados por constitucionalistas acerca de serem efetivamente aqueles direitos de defesa verdadeiros direitos fundamentais.

Por outro lado, enquanto na teoria constitucional a expressão direitos fundamentais parece predominante, no plano do direito internacional 
se encontram expressivos desenvolvimentos teóricos acerca dos direitos humanos, ${ }^{1}$ sem que se saiba com exatidão estar-se diante do mesmo objeto ou não.

Além dos ditos problemas de definição, isto é, do que sejam ou não direitos fundamentais, não há ainda nenhum consenso acerca de qual seja a estrutura lógica desses direitos e que notas características eles têm que lhes atribuam o predicado de fundamentalidade. Em outros termos, a razão de ser deste trabalho é a dissenso sobre o que sejam direitos fundamentais e o que implica terem alguns direitos este atributo.

Exatamente porque a análise parte do dissenso, é que se baseia em autores que não só divergem em suas conclusões sobre o tema, como partem de premissas diversas. E o fato de se abordarem, por exemplo, definições de autores bastante divergentes (como Alexy e Vieira de Andrade) não significa falta de consciência do dissenso entre eles. Ao contrário, o que se buscará é apontar convergências existentes mesmo em autores, em geral, contrapostos, até porque, embora trilhando caminhos completamente diferentes e chegando a negar (ainda que não nominalmente) alguns pontos de partida um do outro, autores como Lenio Streck, de um lado, e Virgílio Afonso da Silva, de outro, almejam um mesmo fim, maior eficácia aos direitos fundamentais.

O presente estudo, portanto, tenta identificar os predicados que caracterizam como fundamentais alguns direitos (e que às vezes podem ser encontrados em autores contrapostos), bem como que estrutura lógica eles têm em comum que torne sua aplicação algo específico. Em outros termos, a tentativa é de definir o que torna certos direitos "fundamentais" e o que este predicado implica de diferente em termos de modo de aplicação e definição de contéudo. Isso, por sua vez, permitirá melhor identificar qual o conteúdo normativo, deôntico, de algumas normas constitucionais que hoje são cogitados em decisões judiciais, no fundo, apenas como instrumento retórico, como "interesse público", praticabiliade da tributação e até eventuais "deveres fundamentais". Não que eles serão objeto de análise específica aqui, de modo algum. O que se pretende é apenas fixar premissas que permitam uma melhor análise de argumentos baseados nessas razões.

1 Neste sentido: SARLET, Ingo Wolfgang. A eficácia dos direitos fundamentais: uma teoria geral dos direitos fundamentais na perspectiva constitucional. Porto Alegre: Livraria do Advogado, 2009. p. 29. 


\section{As origens históricas e sua afirmação}

Conforme relata Alexy, ${ }^{2}$ a história da institucionalização dos direitos humanos como direitos fundamentais evidencia uma boa dose de desconexão entre ideias e realidade, teoria e prática. Com efeito, o documento apontado como um dos primeiros marcos jurídicos dos direitos fundamentais, a Magna Charta de 1215, não continha direitos baseados em concepções de direitos humanos, mas tão somente liberdades, que se aperfeiçoaram com as revoluções inglesas do século XVII e, mais ainda, com a Declaração de Direitos da Virgínia, de 1776, que teria sido a primeira a positivar um catálogo completo de direitos fundamentais. ${ }^{3}$

No mesmo sentido, Vieira de Andrade ${ }^{4}$ afirma que a Magna Charta de 1215 não seria o marco inicial de direitos fundamentais, por se tratar de um rol de direitos estatamentais, direitos de "desigualdade", bem diferente de como os veríamos hoje: "verdadeiros direitos ou liberdades, reconhecidos em geral aos homens ou a certas categorias de entre eles, por razões de 'humanidade'"'.

Só a partir das revoluções inglesas do século XVII, portanto, é que aqueles direitos de liberdade teriam começado a se pronunciar como formulações gerais, dirigidas a todos, mas, ainda assim, sem a robustez da declaração francesa dos direitos do homem e do cidadão, de 1789. Por outro lado, somente com sua constitucionalização, a partir das declarações norte-americanas, é que os direitos fundamentais passaram a efetivamente limitar o poder do Estado. ${ }^{6}$

Apesar de a Alemanha ser hoje um dos grandes palcos dos direitos fundamentais, lá a evolução teria sido bastante vacilante, positivando-seos inicialmente apenas em nível regional e, mesmo assim, de forma muito

2 ALEXY, Robert. Tres escritos sobre los derechos fundamentales y la teoría de los principios. Tradução colombiana de Carlos Bernal Pulido. Bogotá: Universidad Externado de Colombia, 2003. p. 32-34. (Serie de Teoría Jurídica y Filosofía del Derecho, n. 28).

3 Ibid., p. 32-34.

4 ANDRADE, José Carlos Vieira de. Os direitos fundamentais na Constituição Portuguesa de 1976. Coimbra: Almedina, 2004. p. 20-22.

5 “Constatou-se então com irrecusável veracidade que as declarações antecedentes de ingleses e americanos podiam talvez ganhar em concretude, mas perdiam espaço de abrangência, porquanto se dirigiam a uma camada social privilegiada (os barões feudais), quando muito a um povo ou a uma sociedade que se libertava poiliticamente, conforme era o caso das antigas colônias americanas, ao passo que a Declaração francesa de 1789 tinha por destinatário o gênero humano. Por isso mesmo, e pelas condições da época, foi a mais abstrata de todas as formulações já feitas acerca da liberdade." BONAVIDES, Paulo. Curso de direito constitucional. São Paulo: Malheiros, 2006. p. 562.

6 José Carlos Vieira de Andrade, Os direitos fundamentais na Constituição Portuguesa de 1976, op. cit., p. 20-22. 
instável, tendo sido a Constituição de Weimar, de 1919, o primeiro catálogo nacionalmente positivado. ${ }^{7}$

Até então se tinha a feição liberal clássica dos direitos fundamentais, inaugurada pela Declaração da Virgínia de 1776. Só em 1918 é que teriam ingressado nas ideias sobre direitos fundamentais as concepções socialistas, da Constituição da União das Repúblicas Socialistas Soviéticas. ${ }^{8}$

Hoje, o cenário é mais completo, pois além de as constituições atuais do período pós-guerra darem sólida proteção às liberdades democráticas clássicas, esses documentos também têm inúmeras e expressivas prescrições de dimensão social, ${ }^{9}$ mais especificamente, direitos prestacionais. É dizer, não se garantem mais somente instrumentos de defesa contra o Estado, mas também de exigência de condutas positivas, não só garantindo o exercício em si de direitos fundamentais (como à educação), como intervindo nas relações entre os próprios cidadãos.

Tem-se, atualmente, amplo consenso de que direitos fundamentais também podem garantir intervenções do Estado contra violações praticadas por outros indivíduos e de que são também direitos à implementação e organização de procedimentos para sua fruição. ${ }^{10}$

Portanto, os que se identificam atualmente como direitos fundamentais são, além das liberdades clássicas, os direitos prestacionais (sociais), bem como os direitos à intervenção estatal contra violações daquelas primeiras liberdades por particulares, o que, no modelo clássico, não era vislumbrado. Como se disse, historicamente, os direitos fundamentais eram defesa contra o Estado e não contra outros particulares.

Salientar a vinculação histórica entre as noções de direitos humanos e direitos fundamentais evidencia que elas não se confundem, ao menos em termos de perspectivas sob as quais o fenômeno é visto. Se uma deriva da outra, é porque não são exatamente a mesma coisa.

Parece que direitos humanos são uma noção um pouco mais estrita que direitos fundamentais; é o que se tentará explicar.

7 Robert Alexy, Tres escritos sobre los derechos fundamentales y la teoría de los principios, op. cit., p. 32-34.

8 Ibid.

9 José Carlos Vieira de Andrade, Os direitos fundamentais na Constituição Portuguesa de 1976, op. cit., p. 25.

10 Robert Alexy, Tres escritos sobre los derechos fundamentales y la teoría de los principios, op. cit., p. 36 . 


\section{As diferentes perspectivas para definir direitos humanos e direitos fundamentais}

Os direitos fundamentais, para Vieira de Andrade, ${ }^{11}$ podem ser vistos em diferentes perspectivas: i) uma filosófica ou jusnaturalista, como direitos inerentes à condição humana, independentemente dos contextos histórico e geográfico; ii) outra constitucional, como os direitos mais importantes de uma ordem jurídica determinada em termos de tempo e lugar e, ainda; iii) numa perspectiva universalista ou internacionalista, como direitos inerentes à condição humana, num certo tempo, mas sem limitações geográficas.

Mas, segundo o autor, teria sido pela concepção filosófica que os direitos fundamentais começaram a ser percebidos, $^{12}$ e a filosofia cristã teria dado forte contribuição à densidade dessas ideias, apesar de não ter sido suficiente para "gerar a ideia de direitos humanos fundamentais no sentido atual". ${ }^{13}$

Alexy ${ }^{14}$ explica que direitos humanos são suprapositivos ou morais, mas uma Constituição só se justifica quando os contemple como direitos fundamentais, ou seja, quando os positive, frisando sempre que um catálogo de direitos fundamentais não precisa conter "somente direitos humanos".

A partir do pressuposto de que direitos fundamentais são, na sua "dimensão natural, absolutos, imutáveis e intemporais" e estão sobrepostos a qualquer ordem jurídica, é que se recorre até hoje a essa concepção diante de dificuldades na aplicação dos direitos fundamentais positivados. ${ }^{15}$

$\mathrm{Na}$ perspectiva internacional, após relatar que as normas de direito internacional relativas a direitos humanos são reconhecidas pela Constituição portuguesa, Vieira de Andrade ${ }^{16}$ admite ainda haver dissenso acerca do seu caráter "supralegal" ou não. De todo modo, lembra que ultimamente a "agenda dos direitos humanos" tem sido dominada pelo direito internacional. ${ }^{17}$

11 José Carlos Vieira de Andrade, Os direitos fundamentais na Constituição Portuguesa de 1976, op. cit., p. 15.

12 Ibid.

13 Ibid., p. 17.

14 ALEXY, Robert. Teoría del discurso y derechos humanos. Tradução colombiana de Luis Villar Borda. Bogotá: Universidad Externado de Colombia, 1995. p. 63, nota 43. (Serie de Teoría Jurídica y Filosofía del Derecho, n. 1)

15 José Carlos Vieira de Andrade, Os direitos fundamentais na Constituição Portuguesa de 1976, op. cit., p. 19.

16 Ibid., p. 32.

17 Ibid. 
Há quem afirme que somente com a positivação dos direitos humanos no catálogo de direitos fundamentais de uma constituição eles ganhariam caráter obrigatório. ${ }^{18}$ Os direitos humanos adquiririam, destarte, caráter positivo mediante os direitos fundamentais. ${ }^{19}$

Segundo Vieira de Andrade, ${ }^{20}$ esta escala dos direitos humanos aos direitos fundamentais pode ser vista em uma "dimensão constitucional positiva", pela qual as perspectivas dos direitos fundamentais e humanos formariam círculos concêntricos, sendo o dos direitos naturais o mais estrito e o dos direitos constitucionais o mais largo.

Os direitos humanos seriam os mais restritos por se limitarem àqueles diretamente ligados à dignidade da pessoa humana, ao qual o direito constitucional agrega liberdades cívicas, direitos políticos, econômicos, sociais e culturais. No entanto, esses "acréscimos" constitucionais não representam, na visão do autor, uma exigência inafastável da natureza humana, mas apenas "derivam dela num segundo grau e tomam a sua forma em virtude das particulares circunstâncias históricas e sociais em que se desenrola a vida dos indivíduos".$^{21}$

A intereação seria em ambos os sentidos, pois os direitos fundamentais positivados se relacionariam muito com as outras dimensões, como a dimensão natural, porque foram eles a sua base material; e como dimensão internacional, porque nela busca muito de sua legitimidade, nos momentos de sua efetivação. ${ }^{22}$

Alexy $y^{23}$ apresenta três concepções de direitos fundamentais, uma formal, outra material e uma terceira, procedimental.

Formalmente, direitos fundamentais são aqueles catalogados como tais, destacando-se a simplicidade desta perspectiva como principal vantagem e, conversamente, a desvantagem relativa ao fato de que muitas constituições apresentam direitos fundamentais fora desse catálogo. ${ }^{24}$

No caso do direito alemão, esta positivação fora do catálogo de direitos fundamentais é expressa na própria Lei Fundamental, que, em seu art. 93,

18 Robert Alexy, Teoría del discurso y derechos humanos, op. cit., p. 93.

19 Robert Alexy, Tres escritos sobre los derechos fundamentales y la teoría de los principios, op. cit., p. 34 .

20 José Carlos Vieira de Andrade, Os direitos fundamentais na Constituição Portuguesa de 1976, op. cit., p. 37-38.

21 Ibid.

22 Ibid., p. 39-40.

23 Robert Alexy, Tres escritos sobre los derechos fundamentales y la teoría de los principios, op. cit., p. 21.

24 Ibid. 
$\S 1^{\circ}$, classifica como direito fundamental todos os direitos que puderem ser defendidos pelos indivíduos por meio de remédios constitucionais. Mas o autor ressalva que este "suprimento" do conceito formal de direito fundamental só é possível em casos como o alemão, em que uma norma constitucional processual deste tipo se refere a "todos" os direitos fundamentais e "somente" a direitos fundamentais. ${ }^{25}$

Outro problema da concepção formal de direitos fundamentais é que no próprio catálogo, por vezes, há disposição que não regula nenhum destes direitos, a exemplo do dispositivo do catálogo de direitos fundamentais da constituição alemã que regula o "status orgânico" dos deputados. ${ }^{26}$

Já numa perspectiva material, exatamente por isso, têm-se conceitos variáveis, a depender da matéria que se inclua nessas definições. Por exemplo, Alexy cita a proposta de Carl Schmitt, ${ }^{27}$ de que direitos fundamentais seriam somente aqueles titularizados por indivíduos, unicamente contra o Estado e tendo por objeto abstenções na intervenção na esfera de liberdade do titular (indivíduo). Portanto, aqui se tinham excluído os direitos prestacionais. ${ }^{28}$

Por isso, Alexy ${ }^{29}$ lembra que tais concepções de direitos fundamentais, decorrentes de uma concepção específica de Estado (no caso, o liberal clássico), precisam ser unidas a outras, das quais decorram princípios diferentes, que devem, por sua vez, ser harmonizados. Portanto, materialmente falando, haveria diferentes classes de direitos fundamentais, com conteúdos de tipos diversos.

A concepção material é também importante porque vincula direitos fundamentais e direitos humanos, sendo os direitos fundamentais os direitos humanos positivados constitucionalmente, como diz Alexy. ${ }^{30}$

Apesar disso, o próprio autor admite que os direitos humanos (que para ele são apenas morais) não preenchem todo o rol dos direitos fundamentais,

25 Robert Alexy, Tres escritos sobre los derechos fundamentales y la teoría de los principios, op. cit., p. 22.

26 Ibid., p. 23.

27 SCHMITT, Carl. Teoría de la Constitución. Tradução espanhola de Francisco Ayala. Madri: Alianza, 2006. p. 168-174.

28 Robert Alexy, Tres escritos sobre los derechos fundamentales y la teoría de los principios, op. cit., p. 24-25.

29 Ibid.

30 Ibid., p. 26. No mesmo sentido: COMPARATO, Fábio Konder. Rumo à justiça. São Paulo: Saraiva, 2010. p. 57 e 266. Entretanto, para este último autor, os direitos humanos, reconhecidos no "meio social"e no plano internacional, estão todos sobrepostos às constituições (ibid., p. 266). Além disso, a positivação de todos os direitos humanos faria perder sentido a distinção (ibid., p. 65). 
pois o catálogo pode incluir entre os direitos fundamentais alguns que não sejam necessariamente "humanos", ou seja, o catálogo de direitos fundamentais pode conter mais que direitos humanos, o que não pode é conter menos, sob pena de ser "insuficiente". ${ }^{31}$

Ele frisa também que na Constituição alemã os direitos humanos são reconhecidos expressamente como anteriores e superiores, pelo fato de o §2o, do art. 1ํ, da Lei Fundamental declarar que o povo alemão "reconhece" os direitos humanos e os têm como "invioláveis" e "inalienáveis", além de fundamentais para toda "comunidade humana". ${ }^{32}$ Entretanto, Alexy não deixa de reconhecer que o conceito de direitos humanos é bem indeterminado. ${ }^{33}$

Na opinião de Vieira de Andrade, ${ }^{34}$ a Constituição portuguesa não atribui a si a "criação" dos direitos fundamentais, mas "reconhece" em seu conteúdo essencial os direitos naturais, exatamente como algo que não estava à disposição nem do próprio Poder Constituinte. Por isso, a assertiva de Alexy, ${ }^{35}$ de que a aplicação comum de direitos humanos e fundamentais só será possível quando se decidirem as divergências sobre os conceitos daqueles.

Além dessas aproximações formal e material, haveria uma procedimental. Procedimentalmente definidos, os direitos fundamentais são tão importantes que sua "proteção" ou "não proteção" não pode ficar a critério de maiorias parlamentares. ${ }^{36}$ Essa definição é procedimental porque se baseia na questão acerca de quem, e de que modo, tem competência para decidir sobre direitos fundamentais. ${ }^{37}$

As aproximações são complementares. A perspectiva formal da definição permite que quem detenha o poder decisório sobre os direitos fundamentais (o Constituinte) possa considerar fundamentais certos direitos que não são "humanos", mas, ainda assim, são importantes o suficiente para serem positivados constitucionalmente. ${ }^{38}$

31 Robert Alexy, Tres escritos sobre los derechos fundamentales y la teoría de los principios, op. cit., p. 26.

32 "Das Deutsche Volk bekennt sich darum zu unverletzlichen und unveräuBerlichen Menschenrechten als Grundlage jeden menschlichen Gemeinschaft, des Friedens und Gerechtigkeit in der Welt." Tradução livre: O povo alemão reconhece, por serem invioláveis e inalienávies, os direitos humanos como fundamento de toda comunidade, da paz e da justiça no mundo.

33 Robert Alexy, Tres escritos sobre los derechos fundamentales y la teoría de los principios, op. cit., p. 27.

34 José Carlos Vieira de Andrade, Os direitos fundamentais na Constituição Portuguesa de 1976, op. cit., p. 46.

35 Robert Alexy, Tres escritos sobre los derechos fundamentales y la teoría de los principios, op. cit., p. 27.

36 Ibid., p. 29.

37 Ibid., p. 30-31.

38 Ibid. 
Para Alexy, ${ }^{39}$ esta "importância" (que justificou a inserção formal) atribui uma "índole material" ao conceito procedimental e, como materialmente há vinculação entre direitos fundamentais e direitos humanos, a aplicação dos direitos fundamentais deve buscar sempre avançar na concepção de direitos humanos, especialmente, levando-se em conta a "pretensão de correção" inerente a esses.

As conclusões que se podem tirar inicialmente são que todo direito humano é direito fundamental, mas nem todo direito fundamental será necessariamente um direito humano. Sabe-se que essa afirmação pode trazer à tona um debate entre o caráter universal dos direitos humanos e o respeito ao multiculturalismo, ${ }^{40}$ mas ele fugiria ao escopo deste trabalho, que não busca definir direitos humanos, mas sim fundamentais.

Em outras palavras, não se tratará aqui da discussão acerca de Estados em que posições jurídicas consensualmente consideradas direitos humanos no universo da cultura ocidental, como igualdade entre os gêneros, não são posições reconhecidas como tal em culturas islâmicas, por exemplo.

Aqui se poderia levantar a questão acerca de se ter um direito, para o mundo ocidental, inegavelmente humano, mas que não seria reconheciddo como tal em uma série de Estados orientais. Parece que o melhor modelo teórico para análise destes problemas é aquele de reaproximação entre direito e moral, proposto por Alexy," por meio da noção de "pretensão de correção do direito".

No entanto, como dito, tal discussão foge aos limites deste trabalho, que toma como parâmetro as constituições de Estados democráticos de direito que têm todos os direitos humanos como direitos fundamentais e, em alguns casos, fundamentalizam alguns outros cuja natureza humana seja até discutível, como o direito de propriedade.

Feitas essas considerações gerais sobre as definições de direitos fundamentais, sua distinção em relação aos direitos humanos e, especialmente, a

39 Ibid.

40 A discussão poderia surgir em torno do que seria "inerente" à natureza humana, pois tais concepções podem variar muito se forem comparadas algumas culturas ocidentais e orientais. E até por desconhecimento acerca dos fundamentos de culturas islâmicas, por exemplo, é que se evita rotular de "universal", por exemplo, a igualdade de gêneros. Um debate interessante sobre a existência ou não de uma moral universal e a tentativas de teorias discursivas de definir a questão pode ser vista em: MINEUR, Didier. The moral foundation of law and the ethos of liberal democracies. Ratio Juris, v. 25, n. 2, p. 133-148. jun. 2012.

41 ALEXY, Robert. Conceito e validade do direito. Tradução brasileira de Gercélia Batista de Oliveira Mendes. São Paulo: WMF Martins Fontes, 2009. 
partir da conjugação dos conceitos formal, material e procedimental proposto por Alexy, é que se passará à análise dogmática do direito constitucional brasileiro.

\section{Os direitos fundamentais na Constituição brasileira de 1988}

Os direitos fundamentais estão formalmente catalogados no art. $5^{\circ}$ da Constituição da República Federativa do Brasil de 1988, em mais de 70 incisos. Por outro lado, o $\$ 2$ deste artigo tem uma cláusula de abertura material mais ampla do que aquela "procedimental" inserida na Lei Fundamental alemã. ${ }^{42}$

É que, enquanto lá a Constituição diz que são direitos fundamentais quaisquer uns postos naquele documento e passíveis de serem objeto de um remédio constitucional, aqui são materialmente direitos fundamentais todos os outros decorrentes do regime e dos princípios adotados pela Constituição de 1988, nos termos do $\S 2$, do citado art. $5^{\circ}$.

Também ganham status constitucional (equivalentes a emendas) aqueles quaisquer direitos humanos que sejam objeto de tratados internacionais que formalmente passem pelo processo descrito no $3^{3}$, do art. 5o.

Mas, voltando ao tema dos direitos fundamentais decorrentes do regime e dos princípios adotados pela Constituição, pode ser posta novamente aquela dúvida acerca de alguns direitos, como as limitações ao poder de tributar. É de se questionar: se os tributos são o preço da liberdade ${ }^{43} \mathrm{e}$, da sua instituição, arrecadação e fiscalização depende a própria concretização e eficácia dos direitos fundamentais (inclusive, os de cunho mais classicamente liberal), seriam as cláusulas de defesa à tributação direitos fundamentais?

42 Trata-se do art. 93, §1ํ, n. 4, a, da Lei Fundamental alemã, que garante recurso constitucional a "todos os direitos fundamentais", bem como a "outros direitos" previstos em artigos esparsos, pelo que, em termos procedimentais, aquele texto constitucional estende a garantia típica dos direitos fundamentais e outros direitos que, não osbtante não sejam "materialmente" fundamentais, sejam formalmente positivados pela constituição. "Art. 93. Das Bundesverfassungsgerichte entcheidet: 4.a. über Verfassungsbeschwerden, die von jedermann mit der Behauptung erhoben werden können, durch die öffentliche Gewalt in einem seiner Grundrechte oder in einem seiner in Artikel 20, Abs. 4, 33, 38, 101, 103 und 104 enthaltenen Rechte verletzt zu sein." Tradução livre: O Tribunal Constitucional Federal alemão decidirá sobre recursos constitucionais, que podem ser interpostos por todos os cidadãos, sob o argumento de terem sido prejudicados pelo Poder Público em seus direitos fundamentais ou em um dos seus direitos previstos no art. 20, parágrafos 4o , 33, 38, 101, 103 e 104.

43 HOLMES, Stephen; SUNSTEIN, Cass R. The cost of rights: why liberty dependes on taxes. Nova York; Londres: W. W. Norton \& Company, 2000. 
É preciso lembrar que há influentes definições de direitos humanos como aqueles inerentes universalmente à condição de pessoa, como se vê, por exemplo, em Comparato ${ }^{44}$ e também em Bonavides, ${ }^{45}$ o que leva ao questionamento da natureza "humana" do direito de propriedade, por exemplo.

Não obstante a própria Declaração Universal dos Direitos do Homem prescreva expressamente o direito de propriedade ${ }^{46}$ tendemos a concordar com esses autores. Não parece que um Estado que adote o modo de produção socialista ou, até mesmo, qualquer um outro que um dia se venha a vislumbrar e que não se baseie na propriedade privada dos meios de produção, seja violador de direitos humanos. É uma questão diferente se empiricamente percebam-se desrespeitos de várias formas a uma série de direitos essencialmente humanos em regimes jurídicos de viés socialista. Não se estão considerando aqui regimes concretos. Até porque também há uma série de violações a direitos humanos em regimes não só democráticos, mas altamente capitalistas, como o caso do Brasil.

O fato é que "humano" ou não, além da Declaração Universal dos Direitos do Homem, de 1948, o direito de propriedade consta expressamente do catálogo de direitos e garantias fundamentais constante do art. 5o da Constituição brasileira de 1988. Mas, ainda assim, se, como explicam Holmes e Sunstein, ${ }^{47}$ o próprio direito de propriedade, para sua eficácia, depende de um Estado organizado e atuante nesse sentido, e o regime de livre-iniciativa adotado pela Ordem Econômica da Constituição, em geral, retira o Estado do mercado, como explica Schoueri, ${ }^{48}$ este ente necessariamente precisa de tributos para cumprir suas atribuições.

Portanto, se os tributos são o preço da liberdade e, na verdade, de todos os direitos fundamentais, seriam as limitações a eles também direitos fundamentais?

Essa questão parece ter resposta afirmativa quase intuitiva por parte daqueles que lidam juridicamente com tributos, prática ou academicamente,

44 COMPARATO, Fábio Konder. A afirmação histórica dos direitos humanos. São Paulo: Saraiva, 2010. p. 24-49.

45 Paulo Bonavides, Curso de direito constitucional, op. cit., p. 565-569.

46 Declaração Universal dos Direitos do Homem, art. 17, 1 . Todo ser humano tem direito à propriedade, só ou em sociedade com outros. 2. Ninguém será arbitrariamente privado de sua propriedade.

47 Stephen Holmes e Cass. R. Sunstein, The cost of rights, op. cit., p. 35-83.

48 SCHOUERI, Luís Eduardo. Tributação e liberdade. In: PIRES, Adilson Rodrigues; TÔRRES, Heleno Taveira (Coord.). Princípios de direito financeiro e tributário: estudos em homenagem ao professor Ricardo Lobo Torres. Rio de Janeiro: Renovar, 2006, p. 462. 
a exemplo de Schoueri. ${ }^{49}$ Mas é curioso como qualquer revisão bibliográfica que se faça em termos de direito constitucional e, especialmente, direitos fundamentais não leva a questões envolvendo tributação, salvo como exemplos incidentais em raríssimos casos. ${ }^{50}$

O que se quer dizer é que a leitura de modelos teóricos criados na seara do direito constitucional, ao tratarem de tipos de direitos fundamentais, seus modelos de estrutura lógica e classificação de contéudo, trata das liberdades clássicas (como a política e de expressão), dos direitos sociais, econômicos, culturais, ao meio ambiente, sem que, salvo raras exceções, se vislumbre a matéria tributária.

Uma das únicas exceções na bibliografia de direitos fundamentais é Martin Borowski, ${ }^{51}$ que cita como exemplo de aplicação das teorias funcionais dos direitos fundamentais um caso de tributação extrafiscal. ${ }^{52}$

Um bom exemplo disso é um dos modelos teóricos que mais influenciam este trabalho, que é a Teoria dos direitos fundamentais, de Robert Alexy, em cujas mais de 600 páginas, repletas de exemplos práticos e concretos, não se encontram referências aos tributos. O mesmo se diga em relação, por exemplo, à doutrina de José Carlos Vieira de Andrade, com a qual este trabalho dialoga muito criticamente.

49 SCHOUERI, Luís Eduardo. Princípios no direito tributário internacional: territorialidade, fonte e universalidade. In: FERRAZ, Roberto (Coord.). Princípios e limites da tributação. São Paulo: Quartier Latin, 2005. p. 321-374.

50 SILVA, Virgílio Afonso da. Princípios e regras: mitos e equívocos acerca de uma distinção. Revista Latino-Americana de Estudos Constitucionais, Belo Horizonte, n. 1, p. 613 e 617, jan./jun. 2003.

51 BOROWSKI, Martin. La estrutura de los derechos fundamentales. Tradução colombiana de Carlos Bernal Pulido. Bogotá: Universidad Externado de Colombia, 2003. p. 209-213. (Série de Teoría Jurídica y Filosofía del Derecho, n. 25). Após dar exemplo de uma tributação que favorece negócios de construção civil, Borowski afirma: "Este trato diferenciado se basa en fines externos, consistentes en que un bien colectivo, el negocio de la construcción, se vea favorecido en una cierta crisis. Éste es un fin que no tiene que ver con las personas en un sentido fuerte. En razón de su igual capacidad económica, A y B deven ser gravados prima facie de manera normativamente igual"(p. 212). O autor, ao tratar da igualdade, disitngue tratamentos diferenciados para se atingirem fins internos e fins externos. Um fim interno é perseguido quando o tratamento diferenciado se baseia em características intrínsecas à pessoa ou coisa objeto de comparação, como na realização de direitos fundamentais. Um fim externo é buscado quando se baseiam em propriedades não inerentes a coisas ou pessoas objeto do tratamento diferenciado, como na realização de "bens coletivos". No primeiro caso o tratamento desigual é controlado pela sua adequação a realizar o próprio fim, interno. No segundo, o controle do tratamento desigual se dá pelo exame de proporcionalidade. A perseguição de fins internos só realiza a igualdade, já a de fins externos pode restringi-la, como direito fundamental, pois restringe-se o parâmetro de justiça.

52 Sobre o controle da extrafiscalidade pelo critério da proporcionalidade no direito brasileiro: Schoueri, Luís Eduardo. Normas tributárias indutoras e intervenção econômica. Rio de Janeiro: Forense, 2005. p. 292-295. 
Mas isso não se restringe à análise do direito comparado. Dentre os modelos teóricos dos direitos fundamentais produzidos em relação ao direito brasileiro, o trabalho que mais influencia este é, provavelmente, a tese de titularidade apresentada na Universidade de São Paulo por Virgílio Afonso da Silva, ${ }^{53}$ que também passa ao largo de temas relacionados à tributação.

Um dos poucos contrapontos que se podem mencionar é a obra de Ingo Wolfgang Sarlet, que, ao tratar daqueles direitos fundamentais que, embora estando fora do catálogo do art. 5ํ da Constituição de 1988, seriam formal e materialmente fundamentais, cita, dentre vários exemplos, as "Limitações constitucionais ao poder de tributar". Além disso, o autor fundamenta expressamente sua posição na decisão da ADIn nº 939-7, tomada em 1994 e relatada pelo ministro Sydney Sanches. ${ }^{54}$

Trata-se de Ação Direita de Inconstitucionalidade proposta contra a Emenda no 3/1993 à Constituição de 1988, e contra a Lei Complementar no 77/1993. No que se refere ao imposto sobre movimentações financeiras, conhecido à época por IPMF, pretendeu-se, por meio de emenda à Constituição, sua cobrança no mesmo exercício financeiro de sua instituição, em afronta à regra da anterioridade, prevista no art. 150, III, b, da Constituição, ocasião em que o Supremo Tribunal Federal decidiu que a anterioridade dos tributos não estava à disposição nem do constituinte derivado, por se tratar de cláusula pétrea. .5 $^{5}$

Parece correta a decisão da nossa corte constitucional, bem como a posição de Sarlet. Entretanto, dois pontos merecem ser salientados. Uma passagem geral pela obra do autor revela que a consideração dos tributos foi extremamente isolada, tanto que, em diversas outras passagens em que se faz referência a direitos fundamentais não tão "clássicos" e fora do art. 5o, a alusão que o autor faz é sempre a direitos sociais, econômicos e culturais.

53 SILVA, Virgílio Afonso da. Direitos fundamentais: conteúdo essencial, restrições e eficácia. São Paulo: Malheiros, 2009.

54 Ingo Wolfgang Sarlet, A eficácia dos direitos fundamentais, op. cit., p. 80.

55 O trecho da ementa é o seguinte: 1. Uma Emenda Constitucional, emanada, portanto, de Constituinte derivada, incidindo em violação à Constituição originária, pode ser declarada inconstitucional, pelo Supremo Tribunal Federal, cuja função precípua é de guarda da Constituição (art. 102, I, “a”, da C.F.). 2. A Emenda Constitucional n. 3, de 17.03.1993, que, no art. 2., autorizou a União a instituir o I.P.M.F., incidiu em vício de inconstitucionalidade, ao dispor, no parágrafo 2. desse dispositivo, que, quanto a tal tributo, não se aplica "o art. 150, III, 'b' e VI', da Constituição, porque, desse modo, violou os seguintes princípios e normas imutáveis (somente eles, não outros): 1. - o princípio da anterioridade, que é garantia individual do contribuinte (art. 5., par. 2., art. 60, par. 4., inciso IV e art. 150, III, "b” da Constituição). Sem destaque no original. 
Também cumpre destacar que a referência de Sarlet ao tema dos tributos se referiu expressamente ao art. 150 da Constituição e seus incisos, e não aos direitos de defesa do contribuinte, por exemplo, a tributação conforme a capacidade contributiva ou a seletividade em função da essencialidade dos produtos.

Portanto, é preciso afirmar que os direitos fundamentais devem ser definidos pelas perspectivas formal, material e procedimental e, portanto, no ordenamento brasileiro são direitos fundamentais todos aqueles arrolados no art. $5^{\circ}$ da Constituição (inclusive, as garantias institucionais que ali estão), bem como todas as demais posições jurídicas que assegurem direitos subjetivos que sejam decorrentes do regime e dos princípios adotados pela Constituição (especialmente, o direito geral de liberdade e o princípio da igualdade).

Portanto, de um regime constitucional que se põe como um dos mais analíticos em relação à matéria tributária, com regras e princípios que nada mais são que normas especiais de igualdade e liberdade, só podem decorrer uma série de direitos fundamentais diretamente relacionados à tributação, postos desde o art. 145 da Constituição de 1988, de modo que os direitos fundamentais incluem todos os direitos assegurados ao contribuinte constitucionalmente.

Feita a tentativa de definição do que sejam direitos fundamentais no direito positivo brasileiro, passa-se a uma tentativa de definição de sua estrutura lógica.

\section{A distinção entre regras e princípios}

O presente estudo se pretende como uma análise predominantemente dogmática, com enfoque especialmente analítico. Segundo Alexy, ${ }^{56}$ a dogmática jurídica se desdobra nos planos analítico, empírico e sistemático, que, por óbvio, não podem ser tomados isoladamente em um trabalho acadêmico, mas os limites de abrangência do presente estudo não permitem se enfoquem esses três aspectos.

Em termos analíticos, a dogmática jurídica "diz respeito à dissecação sistemático-conceitual do direito vigente" ${ }^{\prime 7}$ feita com o escopo de sistematização de conceitos formais e materiais, como a definição de norma jurídica, regras, princípios, princípios formais, interpretação e aplicação do direito.

56 ALEXY, Robert. Teoria dos direitos fundamentais. Tradução brasileira de Virgílio Afonso da Silva. São Paulo: Malheiros, 2008. p. 32-33.

57 Ibid., p. 33. 
Empiricamente, duas aproximações são possíveis, segundo Alexy, ${ }^{58}$ a cognição do direito positivo válido, bem como das "premissas empíricas na argumentação jurídica". Mas o autor, expressamente, mantém sua abordagem na primeira. ${ }^{59}$ Por outro lado, "a dimensão empírica não se esgota com a descrição do direito nas leis, pois inclui também a descrição e o prognóstico da práxis jurisprudencial, ou seja, não só o direito legislado, mas também o direito jurisprudencial". ${ }^{60}$ Pois, "devido à abertura de suas normas, a simples cognição do direito legislado não oferece muita coisa". ${ }^{61}$

Não obstante a dita predominância da aproximação dogmática analítica, pretende-se dar parâmetros que levem a proposições também normativas. Quanto a Alexy, este explica que a teoria por ele desenvolvida vai além da exposição do direito válido (empiricamente), para chegar ao plano da "elucidação" e da "crítica da práxis jurídica". ${ }^{2}$ Procura-se, expressamente, neste modelo teórico "a partir do direito positivo válido, determinar qual a decisão correta em um caso concreto". ${ }^{63}$

Como se disse, o presente trabalho parte da distinção entre as três perspectivas postas por Alexy e, por questões de delimitação de objeto, se concentra predominantemente no plano analítico, o que implica tentar definir, além do que sejam direitos fundamentais, qual a estrutura normativa deles, qual seu modo de aplicação e o que a forma deles garante ou deveria garantir.

Claro que esses últimos parâmetros, relacionados ao que está ou deveria estar garantido pela estrutura normativa dos direitos fundamentais, acabam dando margem a considerações normativas, ou seja, aquelas relativas ao conteúdo dos direitos fundamentais. Mas o foco não é definir o conteúdo de um ou vários desses direitos, e sim a estrura comum que eles têm. A menção ao conteúdo de um outro direito fundamental (abordagem normativa) neste trabalho ocorre de forma incidental e exemplificativa.

Feitas essas considerações, a primeira premissa que se precisa fixar é que a distinção entre princípios e regras adotada aqui não é aquela mais utilizada e que diferencia essas espécies normativas com base em graus de generalidade, abstração e importância no ordenamento jurídico, como se vê

\footnotetext{
$58 \quad$ Ibid., p. 34 .

59 Ibid.

60 Ibid.

61 Ibid.

62 Ibid., p. 35.

63 Ibid., p. 36.
} 
em Bandeira de Mello ${ }^{64}$ e que Guastini, ${ }^{65}$ talvez por perceber suas fragilidades, tentou rearranjar.

Normas jurídicas dizem o que deve ser, são ordens, mandamentos, deveres. Enquanto regras são normas compostas pela descrição de uma hipótese e imputação de uma consequência (imposição de uma conduta ou validade de um ato), princípios são normas que estabelecem fins a serem atingidos, ${ }^{66}$ na verdade, a serem buscados, ao máximo possível, salvo limitações fáticas ou jurídicas. ${ }^{67}$

De fato, quando a Constituição impõe fins ou estados em que algo seja realizado ao máximo possível, ela normalmente o faz por meio de $\operatorname{tipos}^{68}$ ou conceitos de termos indeterminados, ${ }^{69}$ todavia não é isso que os caracteriza como princípios. Dois exemplos ajudam a compreender o que se afirma aqui.

Quando o Constituinte garante a liberdade de expressão, ele utiliza um conceito bastante determinado. Não é difícil conceitualmente definir-se o que seja liberdade de expressão, inclusive, porque não é difícil definir-se liberdade e expressão, de modo que parece bastante razoável defini-la como a liberdade de expressar todos os seus pensamentos. No entanto, não há aqui a descrição de uma hipótese normativa e a respectiva imputação de consequência. Até há prescrição de condutas, mas em caráter prima facie e de forma indireta. Quando se garante um "estado ideal" de coisas em que se respeite a liberdade de expressão ou um mandamento de se respeitar, na maior medida possível, a liberdade de expressão, indiretamente se proíbem (ao menos, em princípio) todas as condutas que sejam contrárias a isso e se impõem (ao menos, em princípio) todas as que, entretanto, fomentem esse

64 BANDEIRA DE MELLO, Celso Antônio. Curso de direito administrativo. São Paulo: Malheiros, 2007. p. 86.

65 GUASTINI, Riccardo. Lezioni di teoria costituzionale. Turim: G. Giappichelli, 2001. p. 126-127.

66 ÁVILA, Humberto. Teoria dos princípios: da definição à aplicação dos princípios jurídicos. São Paulo: Malheiros, 2011. p. 71-73.

67 Robert Alexy, Teoria dos direitos fundamentais, op. cit., p. 90-91. Virgílio Afonso da Silva, Direitos fundamentais, op. cit., p. 46.

68 Trata-se aqui da distinção entre tipos e conceitos, no sentido de conceitos serem definições necessariamente determinadas e operáveis por subsunção, como "renda e proventos de qualquer natureza", enquanto tipos são noções históricas, temporais, que evoluem a partir de um núcleo de sentido, como "mulher honesta". Sobre a distinção entre tipos e conceitos ver: GRAU, Eros Roberto. Ensaio e discurso sobre a interpretação/aplicação do direito. São Paulo: Malheiros, 2009. p. 227-244. SCHOUERI, Luís Eduardo. Direito tributário. São Paulo: Saraiva, 2011. p. 603-606.

69 A expressão é de Eros Grau, para quem a indeterminação não está no conceito em si, mas nos termos que os expressam, sendo os conceitos expressados sempre determinados. Eros Roberto Grau, Ensaio e discurso sobre a interpretação/aplicação do direito, op. cit., p. 238-244. 
estado de coisas, de forma semelhante a uma das formas como Humberto Ávila ${ }^{70}$ descreve a estrutura dos princípios.

Por outro lado, quando a Constituição proíbe o confisco por meio de tributos, ela não estatui um "estado ideal de não confisco", mas sim veda que haja qualquer confisco, ela não proíbe apenas "certo grau" de confisco, como se dissesse que "algum" confisco é permitido. A Constituição aqui descreve uma hipótese (tributação confiscatória) e a ela imputa a invalidade jurídica, como consequência definitiva, portanto, por meio de uma regra. ${ }^{71}$ Contudo, não se pode negar que confisco seja um conceito expresso por um dos termos mais indeterminados que existe.

Difícil é saber se determinados fatos se subsumem ou não ao conceito de confisco, mas, feita essa operação lógica de subsunção, impõe-se a nulidade de tais atos estatais. É uma regra hipótetico-condicional que, apesar de não prescrever estritamente uma conduta, por ser norma de (não) competência, impõe à hipótese inevitavelmente a consequência (nulidade). Percebe-se que, ao descrever diretamente uma conduta (em sentido largo) como proibida (tributar com efeito de confisco), a regra de proibição do confisco fomenta um estado ideal de coisas, na verdade, uma série de "fins", postos ao longo de toda a Constituição, como o direito de propriedade, de livre-iniciativa, liberdade de profissão etc.

Assim é que parece pertinente a colocação de Humberto Ávila, ${ }^{72}$ de que princípios são normas jurídicas que prescrevem diretamente fins e indiretamente condutas, já as regras são normas jurídicas que prescrevem diretamente condutas e indiretamente fins.

Apesar da procedência desta descrição dos comandos veiculados por regras e princípios, não será esse o caráter distintivo adotado neste trabalho, mas sim o caráter definitivo ou prima facie dos deveres veiculados pelas normas, bem como seu modo de aplicação. Regras são normas jurídicas que se aplicam por subsunção, pois estabelecem deveres definitivos. Princípios se aplicam por ponderação, pois prescrevem deveres prima facie, determinam que algo seja realizado "na maior medida possível". ${ }^{73}$

Isso significa que seus comandos devem ser realizados ao máximo possível, salvo limitações fáticas à sua concretização, bem como limitações

70 Humberto Ávila, Teoria dos princípios, op. cit., p. 71-72.

71 VIEIRA DA ROCHA, Paulo Victor. Substituição tributária e proporcionalidade: entre capacidade contributiva e praticabilidade. São Paulo: Quartier Latin, 2012. p. 47.

72 Humberto Ávila, Teoria dos princípios, op. cit., p. 71-73.

73 Virgílio Afonso da Silva, Direitos fundamentais, op. cit., p. 44-45. 
jurídicas, postas por outros princípios que estabeleçam outros mandamentos de otimização, cujo fomento, em dado caso concreto, diminua a concretização do primeiro, ${ }^{74}$ sem que, para isso, sejam utilizados quaisquer dos critérios usados nas regras. E isso, primeiramente, porque não há princípio que seja mais específico que outro, salvo nos casos, absolutamente convergentes, como o direito geral de liberdade e pela liberdade de expressão (esta é apenas maior especificação daquele). Segundo, porque estão todos aqueles que estabelecem direitos fundamentais no mesmo plano hierárquico, o constitucional. E, por último, porque estão todos no mesmo referencial cronológico, 5 de outubro de 1988.

A única exceção a isso seria o caso de uma emenda constitucional que estabelecesse um novo princípio, como mandamento de otimização; entretanto, dificilmente a proibição de retrocesso não resolveria a questão como princípio formal, noção que será um pouco mais abordada à frente. De todo modo, os limites deste trabalho não comportam a análise detalhada que esse caso isolado exige.

Quanto às mencionadas limitações à máxima realização dos princípios, como dito, podem ser fáticas ou jurídicas. ${ }^{75} \mathrm{E}$ o parâmetro dessas limitações será sempre outro princípio jurídico, de igual nível hierárquico, no caso dos direitos fundamentais, o nível constitucional. Isto significa que os limites à máxima realização de um princípio não estão nele mesmo, mas em outros princípios. ${ }^{76}$ Uma medida que restrinja essa máxima realização só pode ter por fundamento outro princípio, ou seja, outra norma cujo contéudo também deva ser maximizado.

E essa medida deverá ser adequada e necessária à realização do princípio que serve de fundamento à restrição do primeiro (plano fático). ${ }^{77}$ Além disso, ela precisará ser proporcional em sentido estrito, no sentido de os ganhos que promover em favor do segundo princípio justificarem a restrição em relação ao primeiro (plano jurídico). ${ }^{78}$ Esse raciocínio de ponderação, que aplica um princípio em conjunto com outro, é que não ocorre com as regras.

A partir do momento em que se interpretam textos normativos e se define a hipótese de incidência de uma regra, sua aplicação continuará tão somente no sentido de verficar se determinados fatos sob análise se subsumem ou não

74 Robert Alexy, Teoria dos direitos fundamentais, op. cit., p. 90-91.

75 Ibid., p. 90.

76 Ibid., p. 104.

77 Ibid., p. 118.

78 Ibid. 
a essa hipótese, sem consideração a outras regras. Ainda que se cogitem outras regras com conteúdo que conflitem com o da primeira, a solução dar-se-á por critérios de cronologia, hierarquia e especialidade. Daí serem seus comandos definitivos, a consequência de uma regra é uma só e sua implementação não varia em função de grau, ${ }^{79}$ os limites à regra estão nela mesmos, são imanentes.

Já os princípios estabelecem que, inicialmente (em princípio), sem se considerarem outros princípios (equivalentes em termos de hierarquia, cronologia e especialidade), algo seja realizado ao máximo possível, mas após definida esta devida maximização inicial, verifique-se a existência de fundamento em outro princípio para que se restrinja aquela inicial realização máxima.

Havendo esse fundamento, é que se procederá ao exame de adequação, necessidade e proporcionalidade em sentido estrito da restrição para se chegar, sempre no caso concreto, ao conteúdo definitivo dos princípios em jogo, de modo que o conteúdo de um é diretamente construído em consideração ao conteúdo do outro, tanto em termos fáticos como jurídicos, por dizer-se que instituírem deveres prima facie, que só se tornam definitivos no caso concreto.

Embora Humberto Ávila rejeite essa forma de distinção entre princípios e regras, ${ }^{80}$ a característica da forma direta ou indireta como as normas prescrevem condutas ou fins pode ser verificada nos princípios e regras tal qual diferenciados aqui neste trabalho, mas apenas como uma consequência prática da distinção estrutural dessas normas.

É importante que isto seja dito porque, embora Ávila defenda uma distinção entre essas espécies normativas com base em vários critérios, alguns deles não parecem incompatíveis com esses adotados aqui, a exemplo do caráter direto ou indireto da prescrição de condutas e fins. Isso não quer dizer que as posições sejam de todo "conciliáveis", por exemplo, em função de Humberto Ávila sustentar a possibilidade de se ponderarem regras. ${ }^{81}$

Dessa forma, a definição analítica que se põe neste tópico é a de que regras e princípios não se distinguem pelo grau de generalidade e abstração, tampouco hierarquia (princípios não são superiores nem mais importantes que regras), ou seja, não é uma distinção gradual, mas uma distinção qualitativa, estrutural, por se diferenciarem em função de suas distintas estruturas lógico-normativas, por estabelecerem deveres de forma distinta, que também distintamente devem ser aplicados, um por subsunção e outro por ponderação.

79 Ibid., p. 104.

80 Humberto Ávila, Teoria dos princípios, op. cit., p. 44-45.

81 Ibid., p. 45-50. 
Isso leva à fixação de outro ponto acerca da estrutura dos direitos fundamentais estabelecidos por meio de princípios, à análise do seu âmbito de proteção e de seu suporte fático ${ }^{82}$ ou sua hipótese de incidência.

\section{O âmbito de proteção dos direitos fundamentais e seus limites com base na teoria externa}

Quando se diz que regras estabelecem deveres (e, conversamente, direitos) definitivos e que princípios, deveres (e direitos) prima facie, faz-se necessário apontar que o âmbito de proteção dos direitos fundamentais pode ser diferente, portanto, definitivo ou prima facie.

Nas regras, o âmbito de proteção é definido na hipótese normativa, até porque, nesta espécie de normas, se tem diretamente descrita uma hipótese normativa. Essa é classicamente definida como descrição legal hipotética de fatos ou situações cuja ocorrência implica uma consequência. ${ }^{83}$ No caso dos direitos fundamentais assegurados por princípios, exatamente porque são mandamentos de otimização, se têm direitos prima facie, ou seja, não se tem abstratamente uma hipótese normativa, um suporte fático, um fato gerador, uma hipótese ou uma regra-matriz de incidência.

Aqui duas observações são muito importantes. O âmbito de proteção de um direito é "aquilo que está protegido por ele". ${ }^{84}$ A definição do que esteja protegido por uma regra depende de seu conteúdo mesmo, cotejado com o contéudo de outras regras, por critérios de hierarquia, cronologia e especialidade.

Como a premissa deste trabalho é que o âmbito de proteção de direitos fundamentais garantidos por princípios é o mais amplo possível, ele não pode dizer, em definitivo, no plano abstrato, o que está efetivamente protegido ou não. Nos dizeres de Virgílio Afonso da Silva:

82 Vale ressaltar que em direito tributário é corrente o uso da expressão suporte fático para se referir ao fato jurídico, como premissa menor do raciocínio subsuntivo. Aqui, entretanto, suporte fático será usado em referência à hipótese normativa, por ser a forma utilizada por Virgílio Afonso da Silva, cuja obra é um dos principais referenciais teóricos deste trabalho. Virgílio Afonso da Silva, Direitos fundamentais, op. cit., p. 69-73.

83 Ibid., p. 67.

84 Ibid., p. 71. MENDES, Gilmar Ferreira. Direitos fundamentais e controle de constitucionalidade. São Paulo: Sariava, 2004. p. 13-14. 
toda ação, estado ou posição jurídica que tenha alguma característica que, isoladamente considerada, faça parte do "âmbito temático" de um determinado direito fundamental deve ser considerada como abrangida por seu âmbito de proteção, independentemente da consideração de outras variáveis. ${ }^{85}$

Quando se afirma que a definição do âmbito de proteção desconsidera "outras variáveis" é porque o âmbito de proteção dos direitos fundamentais, como princípios, no plano abstrato, é definido prima facie, por isso a explicação de Afonso da Silva de que definir o âmbito de proteção de um direito fundamental responde à pergunta acerca do que está protegido prima facie por um determinado direito fundamental. ${ }^{86}$

É que a definição do âmbito de proteção é apenas uma parte do suporte fático (hipótese normativa ou hipótese de incidência) de um direito fundamental, ${ }^{87}$ a parte que se definine no plano abstrato. Ela apenas responde que direitos fundamentais, ou melhor, que princípios (direitos fundamentais ou interesses coletivos) estão em jogo e, portanto, sujeitos no caso concreto a uma restrição.

Se os âmbitos de proteção dos direitos fundamentais garantidos por princípios são muito alargados, a tendência é que entrem em colisão com outros direitos fundamentais ou com bens coletivos. E é só nesses casos, somente nesses, que esse âmbito de proteção diminui.

Isso significa que, definida qual regra é aplicável a um dado caso concreto, pelos critérios interpretativos próprios (cronologia, especialidade e hierarquia), seus limites são imanentes, definidos pela relação de subsunção dos fatos à sua hipótese. ${ }^{88}$

Com os princípios é bem diferente; mesmo após se definir que determinada posição jurídica está tematicamente relacionada com um direito fundamental, pode não se dar a proteção definitiva dela, pois pode haver

\footnotetext{
Virgílio Afonso da Silva, Direitos fundamentais, op. cit., p. 109.

Ibid.

Ibid., p. 70 e ss.

88 Humberto Ávila defende que mesmo as regras só têm seu conteúdo definido no caso concreto, por também estarem sujeitas à ponderação e consequente "afastamento". Humberto Ávila, Teoria dos princípios, op. cit., p. 45-50. A posição aqui adotada é a de que a regra só é afastada por uma outra regra resultado da ponderação do princípio cuja realização é fomentada pela primeira com outro princípio que com ela colida. Mas a ponderação ter-se-á dado entre os princípios. Neste sentido: Robert Alexy, Teoria dos direitos fundamentais, op. cit., p. 105 e ss.
} 
justificativas também constitucionais (fáticas ou jurídicas) para que não se concretize naquele caso a proteção que se garantiu prima facie.

Com isso se percebe que a distinção entre princípios e regras por critérios estruturais é incompatível com uma teoria interna, que afirme que direitos fundamentais têm limites imanentes, pois nela os direitos fundamentais impõem todos os deveres definitivamente "visíveis" sem qualquer consideração a outros princípios.

Na teoria externa, no entanto, que fatos ou situações estão previstos em um princípio de forma definitiva, é algo que só se define diante de circunstâncias fáticas e jurídicas externas a tal direito, o que implica afirmar que os princípios não têm "limites imanentes", ${ }^{89}$ negando-se aqui expressamente a premissa metodológica sustentada, por exemplo, por Vieira de Andrade,,$^{90}$ ao seguir a teoria interna.

Assim, o suporte fático de um princípio de direito fundamental é a situação que, quando verificada, implica uma consequência, normalmente, a invalidade do ato que o restringe. Entretanto, só se pode verificar se há ou não restrição a um princípio do direito fundamental diante de circunstâncias fáticas e jurídicas, daí se afirmar que só diante delas é que se define o seu suporte fático, ou seja, seu conteúdo definitivo. ${ }^{91}$

Portanto, não é que regras tenham hipótese de incidência, ou suporte fático, e os princípios não. Como afirma Zagrebelsky, ${ }^{92}$ é que as regras já têm seu suporte fático definido abstratamente, nos dispositivos legais aos quais elas são atribuídas pelo intérprete, portanto, com limites imanentes e conteúdo não sujeito a mitigações. Já os princípios só têm abstratamente um amplo âmbito de proteção, mas seu suporte fático só se define no caso concreto, em consideração a razões normativas externas e colidentes.

Também para Gilmar Mendes a precisa definição das limitações e restrições a direitos fundamentais depende da configuração do seu âmbito de proteção. ${ }^{93}$ Assim, as disposições relacionadas à possibilidade de limitação ou restrição a direitos fundamentais não fazem parte do seu âmbito de proteção, pelo que a inserção de algo no âmbito de proteção de um direito fundamental

89 Virgílio Afonso da Silva, Direitos fundamentais, op. cit., p. 79 e ss.

90 José Carlos Vieira de Andrade, Os direitos fundamentais na Constituição Portuguesa de 1976, op. cit., p. 292-298.

91 Para análise detalhada do embate entre teorias interna e externa na definição do conteúdo dos direitos fundamentais: Virgílio Afonso da Silva, Direitos fundamentais, op. cit., p. 127-163.

92 ZAGREBELSKY, Gustavo. Il diritto mite. Turim: Einaudi, 1992. p. 149.

93 Gilmar Ferreira Mendes, Direitos fundamentais e controle de constitucionalidade, op. cit., p. 13. 
não significa proteção definitiva, "garantindo-se apenas a possibilidade de que determinada situação tenha a sua legitimidade aferida em face de dado parâmetro constitucional", de modo que, "quanto mais amplo for o âmbito de proteção de um direito fundamental, tanto mais se assegura possível qualificar qualquer ato do Estado como restrição" ${ }^{94}$

Isto quer dizer que seus limites são externos, daí, repita-se, falar-se em "teoria externa" acerca dos limites dos direitos fundamentais. Já a teoria interna pressupõe que cada direito fundamental possui limites intrínsecos a ele mesmo, permitindo afirmações, por exemplo, de que determinados cultos não estão protegidos pelo direito fundamental à liberdade religiosa, por não se amoldarem ao conceito de religião que está(ria) no suporte fático deste direito fundamental, pelo que o resultado dessa teoria é um "suporte fático restrito".

Partindo-se de um âmbito de proteção amplo dos direitos fundamentais, tudo que esteja, de alguma forma, tematicamente relacionado a ele, estará neste âmbito de proteção, é dizer, estará protegido em princípio..$^{55} \mathrm{Na}$ verdade, todas as medidas estatais contrárias a ele serão restritivas (em princípio) e não mera regulamentação, conformação ou concretização do direito com base em seus "limites imanentes", postos implicitamente pelo constituinte e apenas "explicitados" pelo legislador ou pelo julgador, com base em concepções majoritárias na sociedade, quando não pessoais. ${ }^{96}$

Se muita coisa está abrangida pelo âmbito de proteção de um direito fundamental, tudo que represente intervenção nele precisará de fundamento de igual nível hierárquico, isto é, o fundamento constitucional será imprescindível, seja ele outro direito fundamental ou um bem coletivo. E se esse não existir, estará preenchido o suporte fático do direito fundamental em questão e se estará diante de um dever de invalidar a restrição, não mais prima facie, mas definitivo, por exemplo. E esse suporte fático é amplo, exatamente porque contempla em concreto tudo que externamente não se puder justificar.

Em outros termos, as limitações ao âmbito de proteção dos direitos fundamentais protegidos por princípios não são imanentes a eles mesmos, senão residem em outras normas constitucionais, que tenham por objeto outros direitos fundamentais ou bens coletivos, daí se falar que seus limites são externos.

\footnotetext{
94 Ibid., p. 14.

95 Virgílio Afonso da Silva, Direitos fundamentais, op. cit., p. 109.

96 Ibid., p. 111-113.
} 
A definição desses limites externos, ou seja, essa aplicação conjunta de princípios, como normas com âmbito de proteção muito ampla, se dá pelo critério da proporcionalidade, abordado brevemente no próximo tópico.

\section{O critério da proporcionalidade}

O juízo de proporcionalidade é muitas vezes vinculado à garantia do devido processo legal e parece ser a posição defendida por Gilmar Mendes, como pode ser visto em alguns trabalhos do autor, afirmando que o devido processo legal "não é o processo da lei, senão a Constituição não precisaria dizer aquilo que é obvio". ${ }^{97} \mathrm{~A}$ origem histórica da cláusula, segundo Mendes, estaria no direito norte-americano, ligada à proteção contra a falta de razoabilidade de normas ${ }^{98}$ afirmando-se também que o "princípio" da proporcionalidade seria instrumento de inibição e neutralização dos abusos cometidos pelos órgãos legislativos e regulamentares..$^{99}$

Já Willis Santiago Guerra Filho sustenta que a vinculação entre o "princípio da proporcionalidade" e o "processo" éideia com grande apoio jurisprudencial e doutrinário, fazendo daquele um princípio "incrustado naquele no qual se assentariam as diversas garantias processuais, de índole constitucional, a saber, o princípio do devido processo legal" ${ }^{100}$ Esta vinculação parece ser também seguida por Luís Roberto Barroso e Ana Paula de Barcellos, ${ }^{101}$ que, por sua vez, também o vinculam a outra ideia, a de razoabilidade. Com efeito, é bastante comum ligar-se a noção de proporcionalidade tanto ao devido processo legal quanto à razoabilidade, cujas origens estariam, por seu turno, na Magna Charta de $1215 .{ }^{102}$

Conquanto haja doutrina e jurisprudência nesse sentido, há quem sustente não haver relação entre a Magna Charta de 1215 e a razoabilidade, muito menos a proporcionalidade. Essa a lição de Virgílio Afonso da Silva, que não

97 Gilmar Ferreira Mendes, Direitos fundamentais e controle de constitucionalidade, op. cit., p. 60.

98 Ibid.

99 Ibid., p. 64-65.

100 GUERRA FILHO, Willis Santiago. Sobre o princípio da proporcionalidade. In: LEITE, George Salomão (Coord.). Dos princípios constitucionais. São Paulo: Método, 2008. p. 237.

101 BARROSO, Luís Roberto; BARCELLOS, Ana Paula de. A nova interpretação constitucional: ponderação, argumentação e papel dos princípios. In: George Salomão Leite (Coord.), Dos princípios constitucionais, op. cit., p. 85-86.

102 KRAKOWIAK, Ricardo. O princípio da proporcionalidade como limitação constitucional ao poder de tributar. Tese (doutorado) - Universidade de São Paulo, São Paulo, 2005. p. 45-46. 
só faz contextualização histórica bem distinta da própria proporcionalidade, como afirma um dos pressupostos teóricos deste trabalho, de que a norma da razoabilidade se distancia, e muito, segundo as concepções aqui adotadas, da norma da proporcionalidade:

É comum, em trabalhos sobre a regra da proporcionalidade, que se identifique sua origem remota já na Magna Carta de 1215. Este documento seria a fonte primeira do princípio da razoabilidade e, portanto, também da proporcionalidade. Essa identificação histórica é, por diversas razões, equivocada. Em primeiro lugar, visto que ambos os conceitos - razoabilidade e proporcionalidade - não se confundem, não há que se falar em proporcionalidade na Magna Carta de 1215. Além disso, é de se questionar até mesmo a afirmação de que a regra da razoabilidade tenha origem nesse documento. Como bem salienta Willis Santiago Guerra Filho, na Inglaterra fala-se em princípio da irrazoabilidade e não em princípio da razoabilidade. E a origem concreta do princípio da irrazoabilidade, na forma como aplicada na Inglaterra, não se encontra no longínquo ano de 1215, nem em nenhum outro documento legislativo posterior, mas em decisão judicial proferida em 1948. E este teste de irrazoabilidade, conhecido também como teste Wednesbury, implica tão somente rejeitar atos que sejam excepcionalmente irrazoáveis. Na fórmula clássica da decisão Wednesbury: "se uma decisão (...) é de forma tão irrazoável, que nenhuma autoridade razoável a tomaria, então pode a corte intervir". Percebe-se, portanto, que o teste sobre a irrazoabilidade é muito menos intenso do que os testes que a regra da proporcionalidade exige, destinando-se meramente a afastar atos absurdamente irrazoáveis. ${ }^{103}$

A proporcionalidade, portanto, não é princípio, pois não tem os atributos que os caracterizam. Pode-se até discutir se é regra formal, metarregra, ou postulado aplicativo normativo, mas, em ambos os casos, é indiscutível que ela, ao contrário dos princípios, não estabelece mandamentos de otimização, nem estados ideais de coisas, nem diretamente fins e indiretamente meios. Ela não é um princípio porque é instrumento de aplicação deles, decorrente de sua própria estrutura lógica.

103 SILVA, Luís Virgílio Afonso da. O proporcional e o razoável. Revista dos Tribunais, São Paulo, n. 798 , p. 29, abr. 2002. 
Se princípios tendem a colidir entre si, por estabelecerem fins a serem buscados e a realização desses fins pode, e muito, ser contraditória entre si, a proporcionalidade é o instrumento de medida do quanto se pode fomentar a realização de um fim restringindo a realização do outro.

Os limites a esta intervenção são postos por um modelo teórico decorrente da estrutura dos direitos fundamentais garantidos prima facie, por meio de princípios, como normas com "suporte fático amplo", definido pela conjugação de um também amplo "âmbito de proteção" e a medida sobre ele interventiva; em outras palavras, o suporte fático (amplo) dos direitos fundamentais é resultado da ponderação entre seu âmbito de proteção (amplo) e a medida que nele intervém. Se a intervenção for desproporcional, será classificada como restrição, proibida, portanto, preenchido estará o suporte fático do direito fundamental e deverá ser a sua consequência a invalidade da norma que o restringe. ${ }^{104}$ Esse é o modelo da proporcionalidade, que se aplica por meio de três sub-regras formais, a de adequação, de necessidade e de proporcionalidade em sentido estrito.

Não se pode deixar de mencionar também sobre o tema a observação de Virgílio Afonso da Silva, ${ }^{105}$ no sentido de haver um caráter sequencial e subsidiário na análise das sub-regras (ou fases, como chama Ávila ${ }^{106}$ ) da proporcionalidade, de forma que somente se analisa a necessidade de uma medida se ela primeiramente for considerada adequada (da mesma forma que só se analisa proporcionalidade em sentido estrito de medida que seja necessária).

Por outro lado, se o ato for inadequado ou desnecessário, interrompendose o teste de proporcionalidade nessas respectivas fases, não quer dizer que ele não se estará aplicando. Ele só não precisará, nesse caso, ser tão aprofundado. Isso permitirá afirmar que a inconstitucionalidade é patente.

Quando se está diante de uma medida que diminua a eficácia de um princípio em favor da realização de outro e, portanto, impõe-se a aplicação proporcional deles, é mister verificar primeiramente a adequação dessa mesma medida ao fomento da concretização do princípio que a fundamenta. ${ }^{107}$ Por óbvio, o fundamento deve ser reconhecido constitucionalmente. ${ }^{108}$

\footnotetext{
104 Virgílio Afonso da Silva, Direitos fundamentais, op. cit., p. 72-75.

105 Luís Virgílio Afonso da Silva, O proporcional e o razoável, op. cit., p. 34-35.

106 Humberto Ávila, Teoria dos princípios, op. cit., p. 173 e ss.

107 Martin Borowski, La estrutura de los derechos fundamentales, op. cit., p. 129. Virgílio Afonso da Silva, Direitos fundamentais, op. cit., p. 170

108 Virgílio Afonso da Silva, Direitos fundamentais, op. cit., p. 169.
} 
Constatando-se a adequação entre a medida objeto de questionamento e o fim por ela pretensamente almejado, deve-se passar à análise de sua necessidade, o que significa a inexistência de outra medida que fomente com igual intensidade esse princípio objetivado, mas que seja menos restritiva ao outro princípio com ele conflitante. Neste sentido é que Paulo Bonavides fala em a medida interventiva "não exceder os limites indispensáveis à conservação do fim legítimo que se almeja". ${ }^{109}$ (Grifo nosso)

Em ambos os casos, adequação e necessidade, se está diante de uma limitação fática, empírica, à eficácia dos princípios em sua realização máxima, ou seja, a concretização do estado de coisas prescrito pela norma vai até onde faticamente não se encontre outra alternativa à concretização de outro princípio com ele colidente.

Falar que é necessário o meio que restrinja menos o direito fundamental objeto de intervenção, dentre os que promovam igualmente o fim que o justifique, impõe um exame comparativo entre os níveis de adequação: um perquirindo se os meios fomentam igualmente o fim, e outro comparando intensidade de restrição, ${ }^{110}$ exatamente nessa ordem.

Destarte, primeiro é preciso verificar se os meios disponíveis são igualmente adequados; em não o sendo, o mais adequado é também necessário. Sendo um tão adequado quanto o outro, o necessário será o menos restritivo.

Todavia, para que não se retire a competência decisória do legislador, é importante a ressalva de Ávila, de que basta que um meio seja mais adequado que o outro em algum aspecto para que eles não sejam mais considerados igualmente adequados, em outras palavras, "fosse permitido ao poder Judiciário anular a escolha do meio porque ele, em algum aspecto e sob alguma perspectiva, não promove o fim da mesma forma que outros hipoteticamente aventados, a rigor nenhum meio resistiria ao controle de necessidade" ${ }^{111}$

Tal inexistência de alternativa à realização de um princípio que conflite com outro não significa que aquele vá prevalecer. Assim, passa-se à análise das limitações jurídicas à eficácia dos princípios, quando se verifica a proporcionalidade em sentido estrito da medida que realize um princípio restringindo outro.

\footnotetext{
109 Paulo Bonavides, Curso de direito constitucional, op. cit., p. 397.

110 Virgílio Afonso da Silva, Direitos fundamentais, op. cit., p. 171. Humberto Ávila, Teoria dos princípios, op. cit., 170-171.

111 Humberto Ávila, Teoria dos princípios, op. cit., p. 171.
} 
Aqui o que se sopesa é a intensidade da realização de um princípio e a importância da concretização do outro no ordenamento constitucional. ${ }^{112}$

Constatando-se a adequação da medida ao fomento de um princípio, bem como sua necessidade para tanto, impõe-se analisar a importância da realização do bem jurídico por ele tutelado, se ela justifica a intensidade da restrição ao outro bem jurídico em tela, protegido por outro princípio.

Esse é o último momento de definição do suporte fático de um dado direito fundamental objeto de intervenção, o que, como se disse, de acordo com a teoria externa, se dará em relação ao caso concreto, nem que a intervenção "concreta" seja uma lei. A "prevalência" de um princípio sobre o outro não é abstrata.

Na mesma linha, também é importante a observação de Virgílio Afonso da Silva, de que:

Para que uma medida seja reprovada no teste de proporcionalidade em sentido estrito, não é necessário que ela implique a não realização de um direito fundamental. Também não é necessário que a medida atinja o chamado núcleo essencial de algum direito fundamental. Para que ela seja considerada desproporcional em sentido estrito, basta que os motivos que fundamentam a adoção da medida não tenham peso suficiente para justificar a restrição ao direito fundamental atingido. É possível, por exemplo, que essa restrição seja pequena, bem distante de implicar a não realização de algum direito ou de atingir o seu núcleo essencial. Se a importância da realização do direito fundamental, no qual a limitação se baseia, não for suficiente para justificá-la, será ela desproporcional. ${ }^{113}$

A análise, segundo Alexy, deve começar pelo grau de intervenção em um direito e seguir com o exame da "importância" da realização do outro, para se chegar à comparação entre a restrição e o ganho, e verificar sua "justificação" ${ }^{114}$ Percebe-se que o exame é um pouco subjetivo; para Ávila, ${ }^{115}$ ele chega a ser "fortemente" subjetivo, havendo até quem o negue por completo, afirmando

${ }^{112}$ Luís Virgílio Afonso da Silva, O proporcional e o razoável, op. cit., p. 40.

113 SILVA, Luís Virgílio Afonso da Silva, O proporcional e o razoável, op. cit., p. 41.

114 Robert Alexy, Teoria dos direitos fundamentais, op. cit., p. 594.

${ }^{115}$ Humberto Ávila, Teoria dos princípios, op. cit., p. 173. 
que o exame de proporcionalidade só vai até o de necessidade, como Dimoulis e Martins. ${ }^{116}$

Realmente, não se pode negar que as decisões jurídicas mais delicadas, especialmente, em matéria de direitos fundamentais, não deixam de ser também uma escolha política. Ademais, é inerente ao direito a existência de mais de uma resposta correta para uma dada questão, ${ }^{117}$ ao contrário do que sustenta Lenio Luiz Streck, ${ }^{118}$ cabendo mesmo a cada um dos interessados demonstrar ao julgador que a sua proposição é a melhor, por meio de argumentação. Daí a necessidade de a fundamentação do argumento proposto pelas partes e, principalmente, da fundamentação da decisão tomada por quem competente se submeter a regras que impliquem seu controle intersubjetivo. A fundamentação é inerente ao direito, direito sem fundamentação não é direito. ${ }^{119}$ Entretanto, essa análise foge aos limites do presente trabalho, ${ }^{120}$ pois explicar a necessidade de fundamentação das decisões e das normas jurídicas em geral impõe entrar no debate entre aproximação ou separação entre direito e moral, é dizer, a defesa da fundamentação como elemento inerente ao direito vai seguir caminhos completamente diferentes a depender, por exemplo, da premissa de que o direito seja instrumento de planejamento social, como faz Scott Shapiro, ${ }^{121}$ ou de que ele seja instrumento de realização da justiça, o que, por sua vez, implica incluir uma pretensão de correção como elemento intrínseco ao direito, como faz Alexy. ${ }^{122}$

Ao final, é importante frisar, ainda, que o controle de proporcionalidade em sentido estrito é pautado por um princípio formal, inerente ao regime democrático, que é o "princípio da competência decisório do legislador", de que fala Virgílio Afonso da Silva. ${ }^{123}$ De forma muito simplista, equivale

116 DIMOULIS, Dimitri, MARTINS, Leonardo. Teoria geral dos direitos fundamentais. São Paulo: RT, 2009. p. 193-209.

117 Eros Roberto Grau, Ensaio e discurso sobre a interpretação/aplicação do direito, op. cit., p. 40 e 104-108.

118 STRECK, Lenio Luiz. Verdade e consenso: constituição, hermenêutica e teorias discursivas. São Paulo: Saraiva, 2011. p. 69.

119 Uma profunda e detalhada análise do debate entre teorias materias e procedimentais do direito, tendo a fundamentação como foco de debate, pode ser vista em: Lenio Luiz Streck, Verdade e consenso, op. cit., em especial, caps. 3 a 5.

120 A respeito da necessidade inerente ao direito de argumentos intersubjetivamente controláveis, por todos: ALEXY, Robert. Teoria de la argumentación jurídica. Tradução espanhola de Manuel Atienza e Isabel Espejo. Madri: Centro de Estudios Políticos y Constitucionales, 2007.

121 SHAPIRO, Scott J. Legality. Cambridge, MA; Londres: The Belknap Press of Harvard University Press, 2011. p. 195 e ss.

122 Robert Alexy, Conceito e validade do direito, op. cit., p. 41-42.

123 SILVA, Virgílio Afonso da. A constitucionalização do direito: os direitos fundamentais nas relações entre particulares. São Paulo: Malheiros, 2005. p. 148-152. 
a dizer que na dúvida sobre a proporcionalidade em sentido estrito, deve prevalecer a regra questionada, em função da sua origem no órgão que, em tese, representa a vontade majoritária do povo.

Só que todo esse modelo teórico, que propõe direitos fundamentais como objeto de máxima realização, sem limites imanentes, que só podem ter seu âmbito de proteção objeto de uma intervenção se esta tiver uma justificativa também constitucional, que passe pelo teste de proporcionalidade, tem uma razão de ser, com cuja explicação se pretende finalizar este artigo.

\section{A fundamentação de mitigações aos direitos fundamentais}

Ao se falar que direitos fundamentais têm um âmbito de proteção amplo, a ponto de nele estar abrangido toda pretensão que tematicamente possa estar a ele relacionada, ainda que, segundo concepções bastante minoriatárias na sociedade, se pretende dar a tais direitos a maior proteção possível, e não lhes trazer instabilidade.

Ao se afirmar que tais direitos não têm limites imanentes, o que se pretende é que não possa o aplicador da Constituição (legislador e corte constitucional), por força de conceitos ou pré-conceitos majoritários, ou até mesmo subjetivos e pessoais, negar pretensões baseadas em direitos fundamentais sem que aquelas pretensões não impliquem qualquer prejuízo a outro direito fundamental ou bem coletivo, ou mesmo que até implique, senão de uma maneira irrisória, em relação ao grau de realização do primeiro.

Sabe-se que, na prática, muitas vezes os órgãos aplicadores do direito subvertem esse modelo e apenas o aplicam nominalmente, fazendo da ponderação uma porta aberta para a discricionariedade ou até arbitrariedade mesmo, como afirma Streck, ${ }^{124}$ ao fazerem da proporcionalidade, em especial, da ponderação, meros "enunciados performativos". ${ }^{125}$ Mas o fato de seu uso distorcido levar à discricionariedade e decisionismos não invalida o modelo, como pretende Streck. ${ }^{126}$

Por isso, também não procede a crítica de que a ponderação e as teorias procedimentalistas "terminam por servir de álibi teórico para sustentar decisões tomadas de forma antecipada", baseadas em uma abstrata e universalizante

124 Lenio Luiz Streck, Verdade e consenso, op. cit., p. 50.

125 Ibid., p. 55.

126 Ibid., p. 42, 177-179, 194, 199-200. 
hierarquia de princípios. ${ }^{127}$ A crítica aos modelos procedimentalistas que "substituía a razão prática pela razão comunicativa" e que "desoneram o juiz (Judiciário) da tarefa de elaboração do discurso que fundamenta a validade da norma a ser aplicada"128 não se pode dirigir ao modelo de Alexy, que tem como um escopo central a imposição de fortes ônus argumentativos ao aplicador do direito, impedindo-o de negar proteção a direitos fundamentais (garantidos por princípios) por questões subjetivas, como salienta Virgílio Afonso da Silva. ${ }^{129}$

Compreender princípios como mandamentos de otimização não faz deles "cláusulas abertas" nem "espaço reservado à livre atuação da subjetividade do juiz". ${ }^{130} \mathrm{O}$ objetivo principal do modelo teórico aqui descrito analiticamente e defendido é impor um forte ônus argumentativo ao aplicador dos direitos fundamentais, para que não possa simplesmente negar proteção jurídica a uma pretensão, porque nas suas concepções pessoais ou da maioria da sociedade ou, até mesmo, de uma minoria mais influente sobre o Estado, aquela pretensão não se subsume aos "limites imanentes" de um dado direito fundamental.

Assim, pretende-se evitar que se negue proteção à liberdade religiosa, simplesmente porque boa parte da sociedade entende que determinadas práticas "não são religiosas", ou ainda, que se negue a liberdade artística porque, nas concepções de alguns agentes do estado, inclusive magistrados, determinada manifestação não seria "artística nem cultural".

E já que se incluiu a matéria tributária no tema dos direitos fundamentais no começo deste estudo, se visa também por meio destes pressupostos a evitar que se instituam tributos, ainda que, formalmente, por lei, da forma mais abstrata e indeterminada conceitualmente possível, simplesmente para facilitar o exercício do poder de arrecadação e fiscalização, ou ainda, se mitigue a observância da capacidade contributiva individual de cada contribuinte, simplesmente para aumento de arrecadação sub-reptícia ou comodidade da administração tributária.

127 Ibid., p. 179.

128 Ibid., p. 208.

129 Virgílio Afonso da Silva, Direitos fundamentais, op. cit., p. 253.

${ }^{130}$ Lenio Luiz Streck, Verdade e consenso, op. cit., p. 221. 


\section{Conclusões}

Direitos fundamentais podem ser definidos de diversas formas, seja a partir de sua identificação com os direitos humanos, seja a partir de perspectivas mais analíticas, como aquelas mais formais ou procedimentais.

No caso brasileiro, esta definição pode se dar de forma razoavelmente segura a partir do próprio texto constitucional, que, não obstante os defina formalmente por meio de um catálogo, faz uma remissão de cunho material a todos os outros direitos fundamentais que decorram do regime e dos princípios por ele adotados.

Com isso se conclui que o rol constante do art. 5ㅜ, CF/1988, não esgota os direitos fundamentais e, como todos os outros direitos assegurados ao longo do corpo constitucional decorrem dos princípios ou do regime adotados, sua previsão constitucional parece suficiente para lhes atribuir tal "fundamentalidade", ostentando-a, por exemplo, os direitos econômicos, sociais e aqueles que limitam o poder de tributar; em outras palavras, direitos relacionados à tributação são "fundamentais".

A tentativa de se definirem direitos fundamentais neste artigo visa à consequente definição do seu modo de aplicação. Sustenta-se uma definição estrutural para que se fixe previamente o modo de aplicação dos vários direitos fundamentais. Embora se constate a existência de direitos fundamentais veiculados por regras, a maioria deles tem a estrutura de princípios.

Essa definição visa a fixar como premissa que, quando sejam veiculados por meio de princípios, os direitos fundamentais têm um âmbito de proteção o mais amplo possível, cujos limites são externos e só existem na proporcional medida da realização de outros princípios, é dizer, deixar de maximizar a proteção de um princípio só se justifica nos estritos limites fáticos - da adequação e necessidade em relação à realização de outro princípio - e jurídicos, da proporcionalidade em sentido estrito, impostos, em cada caso concreto, externamente, por outros princípios com igual previsão constitucional.

Esses princípios, portanto (salvo, hipótese cuja reserva seja feita pelo próprio constituinte por meio de uma regra), só podem ser restringidos por medidas baseadas em outros princípios constitucionais (que podem até ser regras infraconstitucionais). E essas medidas somente serão válidas se adequadas à realização do princípio contraposto, necessárias à realização deste, e, além disso, justificar-se argumentativamente o ganho em favor de um em detrimento do outro, naquelas circunstâncias do caso concreto. 


\section{Referências}

ALEXY, Robert. Conceito e validade do direito. Tradução brasileira de Gercélia Batista de Oliveira Mendes. São Paulo: WMF Martins Fontes, 2009.

. Teoria de la argumentación jurídica. Tradução espanhola de Manuel Atienza e Isabel Espejo. Madri: Centro de Estudios Políticos y Constitucionales, 2007. . Teoría del discurso y derechos humanos. Tradução colombiana de Luis Villar Borda. Bogotá: Universidad Externado de Colombia, 1995. (Serie de Teoría Jurídica y Filosofía del Derecho n. 1).

. Teoria dos direitos fundamentais. Tradução brasileira de Virgílio Afonso da Silva. São Paulo: Malheiros, 2008.

- Tres escritos sobre los derechos fundamentales y la teoría de los principios. Tradução colombiana de Carlos Bernal Pulido. Bogotá: Universidad Externado de Colombia, 2003. (Serie de Teoría Jurídica y Filosofía del Derecho, n. 28).

ANDRADE, José Carlos Vieira de. Os direitos fundamentais na Constituição Portuguesa de 1976. Coimbra: Almedina, 2004.

ÁVILA, Humberto. Teoria dos princípios: da definição à aplicação dos princípios jurídicos. São Paulo: Malheiros, 2011.

BANDEIRA DE MELLO, Celso Antônio. Curso de direito administrativo. São Paulo: Malheiros, 2007.

BARROSO, Luís Roberto; BARCELLOS, Ana Paula de. A nova interpretação constitucional: ponderação, argumentação e papel dos princípios. In: LEITE, George Salomão (Coord.). Dos princípios constitucionais. São Paulo: Método, 2008. p. 61-88.

BONAVIDES, Paulo. Curso de direito constitucional. São Paulo: Malheiros, 2006.

. Curso de direito constitucional. São Paulo: Malheiros, 2008.

BOROWSKI, Martin. La estrutura de los derechos fundametales. Tradução colombiana de Carlos Bernal Pulido. Bogotá: Universidad Externado de Colombia, 2003. (Série de Teoría Jurídica y Filosofía del Derecho, n. 25).

COMPARATO, Fábio Konder. A afirmação histórica dos direitos humanos. São Paulo: Saraiva, 2010.

DIMOULIS, Dimitri; MARTINS, Leonardo. Teoria geral dos direitos fundamentais. São Paulo: RT, 2009. 
GRAU, Eros. Ensaio e discurso sobre a interpretação/aplicação do direito. São Paulo: Malheiros, 2006.

GUASTINI, Riccardo. Lezioni di teoria costituzionale. Turim: G. Giappichelli, 2001.

GUERRA FILHO, Willis Santiago. Sobre o princípio da proporcionalidade. In: LEITE George Salomão (Coord.). Dos princípios constitucionais. São Paulo: Método, 2008. p. 225-242.

HOLMES, Stephen; SUNSTEIN, Cass R. The cost of rights: why liberty dependes on taxes. Nova York; Londres: W. W. Norton \& Company, 2000.

MENDES, Gilmar Ferreira. Direitos fundamentais e controle de constitucionalidade: estudos de direito constitucional. São Paulo: Saraiva, 2004.

SARLET, Ingo Wolfgan. A eficácia dos direitos fundamentais: uma teoria geral dos direitos fundamentais na perspectiva constitucional. Porto Alegre: Livraria do Advogado, 2009.

SCHOUERI, Luís Eduardo. Normas tributárias indutoras e intervenção econômica. Rio de Janeiro: Forense, 2005.

- Princípios no direito tributário internacional: territorialidade, fonte e universalidade. In: FERRAZ, Roberto (Coord.). Princípios e limites da tributação. São Paulo: Quartier Latin, 2005. p. 321-374.

- Tributação e liberdade. In: PIRES, Adilson Rodrigues; TÔRRES, Heleno Taveira (Coord.). Princípios de direito financeiro e tributário: estudos em homenagem ao professor Ricardo Lobo Torres. Rio de Janeiro: Renovar, 2006. p. 431-471.

SILVA, Luís Virgílio Afonso da. O proporcional e o razoável. Revista dos tribunais, São Paulo, n. 798, p. 23-50, abr. 2002.

SILVA, Virgílio Afonso da. A constitucionalização do direito: os direitos fundamentais nas relações entre particulares. São Paulo: Malheiros, 2005.

. Direitos fundamentais: conteúdo essencial, restrições e eficácia. São Paulo: Malheiros, 2009. . Princípios e regras: mitos e equívocos acerca de uma distinção. Revista Latino-Americana de Estudos Constitucionais, Belo Horizonte, n. 1, p. 607-630, jan./jun. 2003.

ZAGREBELSKY, Gustavo. Il diritto mite. Turim: Einaudi, 1992. 